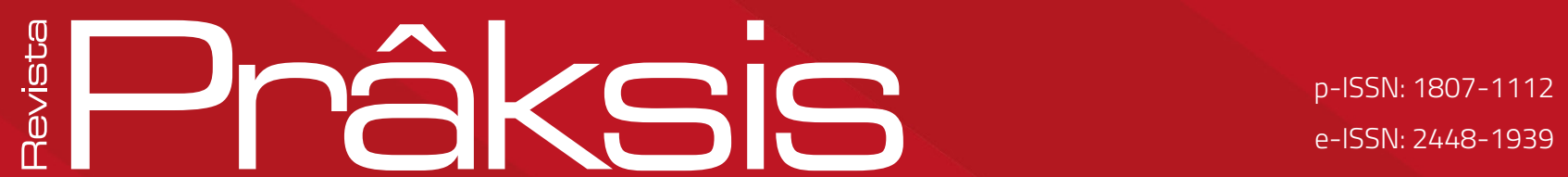

Recebido em: 18 de setembro de 2018

Aprovado em: 20 de janeiro de 2019

Sistema de Avaliação: Double Blind Review RPR |a. 16 | n. 2 | p. 244-266 | mai./ago. 2019

DOI: https://doi.org/10.25112/rpr.v2i0.1890

\title{
QUANDO CIÊNCIA E FUNDAMENTALISMO RELIGIOSO SE ENCONTRAM: ESTRATÉGIAS PARA A PRODUÇÃO DE ÓDIO CONTRA AS SEXUALIDADES E GÊNEROS DISSIDENTES E SEUS EFEITOS NAS POLITICAS PÚBLICAS
}

WHEN SCIENCE AND RELIGIOUS FUNDAMENTALISM MEET: STRATEGIES FOR THE PRODUCTION OF HATE AGAINST DISSIDENT SEXUALITIES AND GENDERS AND THEIR EFFECTS ON PUBLIC POLICIES

\section{Tamires Tolomeotti Pereira}

Doutoranda pela Universidade Federal do Paraná (Curitiba/Brasil).

Mestra em Educação pela Universidade Federal do Paraná (Curitiba/Brasil).

E-mail: tamirestolomeotti@outlook.com.

Jamil Cabral Sierra

Doutor em Educação pela Universidade Federal do Paraná (Curitiba/Brasil). Professor na Universidade Federal do Paraná (Curitiba/Brasil).

E-mail: jamilcasi@gmail.com. 


\section{RESUMO}

Com base nos Estudos de Gênero de vertente pós-estruturalista, o objetivo deste artigo é investigar como os discursos científicos-biológicos têm sido apropriados pelo fundamentalismo religioso nas mídias sociais para a produção de violência e exclusão das sexualidades e gêneros dissidentes. A partir de enunciados extraídos do Twitter de perfis influentes no cenário fundamentalista brasileiro, propõe-se a discussão do seguinte problema: quais os pontos de continuidade e descontinuidade entre os discursos científicos-biológicos e os discursos fundamentalistas religiosos para a legitimação dos discursos de ódio contra as sexualidades e gêneros dissidentes? 0 problema elencado abre espaço para discutir os efeitos da apropriação de elementos científicos-biológicos nos discursos fundamentalistas religiosos, como a reafirmação das terapias de reorientação sexual na contemporaneidade. Além disso, permite a problematização de enunciados que operam como "proteção" à família nuclear, que alavancam a "Ideologia de Gênero", incidindo nas políticas públicas para a diversidade sexual e de gênero e, de modo especial, nas políticas do campo da educação.

Palavras-chave: Diversidade. Educação. Fundamentalismo religioso. Biologia. Mídia.

\section{ABSTRACT}

Based on post-structuralist Gender Studies, the proposal of this article is to investigate how scientificbiological discourses have been appropriated by religious fundamentalism in social media to produce violence and exclusion of dissident sexualities and genders. From statements taken from Twitter of influential personalities in the Brazilian fundamentalist scenario, it is proposed to discuss the following problem: what are the points of continuity and discontinuity between scientific-biological and religious fundamentalist discourses for the legitimation of hate speeches against dissident sexualities and genders? The problem listed here open space to think about the effects of the appropriation of scientific-biological elements in religious fundamentalist discourses, such as the reaffirmation of the sexual reorientation therapies in the contemporary world. In addition, it allows the problematization of statements that operate as a "protection" to the nuclear family, which leverage the "Gender Ideology", focusing on public policies for sexual and gender diversity, and especially in the field of education.

Keywords: Diversity. Education. Religious fundamentalism. Biology. Media. 


\section{INTRODUÇÃO'}

Neste artigo, pensamos a relação entre Ciência, Fundamentalismo Religioso e Diversidade, especialmente com o objetivo de expor estratégias que, em nosso entendimento, têm possibilitado a emergência de discursos de ódio e violência contra as dissidências sexuais e de gênero na atualidade. Estas estratégias, por sua vez, atravessam os saberes científicos-biológicos² que tão bem fizeram/fazem funcionar o dispositivo histórico da sexualidade (FOUCAULT, 2015), no qual se engendram certas noções sobre essas dissidências, sejam elas entendidas como um destino genético, como doenças ou mesmo como desvios de comportamento. Com este movimento, queremos tensionar uma produção científicobiológica sobre a homossexualidade e transexualidade que tem servido a discursos ultraconservadores, dos quais o fundamentalismo religioso é o principal representante, como justificativa para barrar o avanço de políticas públicas no campo da diversidade, especialmente no que se refere a gênero e sexualidade. De modo particular, essa produção cientifico-biológica na qual discursos ultraconservadores e fundamentalistas religiosos se ancoram tem se dado nas mídias sociais, até porque é neste meio que tais discursos parecem ter encontrado sua fonte mais virulenta de reverberação, onde disseminam-se pânicos morais (CÉSAR; DUARTE, 2017), cujos efeitos, para além de sua imprevisibilidade, já estamos experienciando.

No que diz respeito à conquista de direitos e às perspectivas de uma vida vivivel (BUTLER, 2015) para grupos não-hegemônicos, o veto ao projeto "Escola sem Homofobia", em 2011, seria já, naquele momento, um indício da força política ultraconservadora que viveríamos dali em diante. 0 projeto, uma ação dentro do programa mais amplo chamado "Brasil sem Homofobia", incluía a distribuição de materiais didáticos voltados ao combate da discriminação sexual e de gênero que logo ficariam conhecidos pejorativamente como "kit gay". Em 2014, nos episódios de discussão e aprovação do Plano Nacional de Educação (PNE), essas forças retornam com maior truculência e forçam a retirada de qualquer menção à palavra gênero nos documentos educacionais, incluindo os Planos de Educação Estadual e Municipal de

\footnotetext{
${ }^{1}$ Este artigo apresenta, de forma revista, resultados parciais da dissertação de mestrado intitulada "Ciência, Fundamentalismo religioso e Diversidade. A apropriação de discursos científicos-biológicos para a produção de ódio e violência contra as sexualidades e gêneros dissidentes nas mídias sociais", defendida em março de 2018, no Programa de Pós-Graduação em Educação da Universidade Federal do Paraná, que investiga como os discursos científicos-biológicos têm sido apropriados pelo fundamentalismo religioso nas mídias sociais para a produção de violência e exclusão das experiências sexuais e de gênero dissidentes.

2 O uso da expressão "científicos-biológicos" parte do entendimento que as discussões deste texto se inscrevem, de modo geral, na incursão dos corpos e subjetividades dissidentes sexuais e de gênero nas ciências biológicas, considerando que esses saberes foram/são articulados com outros saberes, como os saberes médicos e psi.
} 
vários estados e cidades. Desde então, há uma ameaça constante em relação às discussões de gênero em âmbito escolar, além do cerceamento à liberdade de cátedra suscitado pelo que tem sido chamado de "Ideologia de Gênero" e pelo projeto "Escola sem Partido". Se há pouco nos preocupávamos com a qualidade das políticas públicas, ou mesmo com os avanços e limites que a parceria entre Estado e movimentos LGBT havia produzido, mesmo que sob a lógica da inclusão identitária, o caso agora parece ser outro: estamos vivenciando um período nebuloso, em que sequer há mais a outrora parceria com o Estado que presenciávamos em governos anteriores (SIERRA, 2013; DAL'IGNA; SIERRA, 2018).

É daí que parte nossa aposta: no contexto das mídias sociais, como o Twitter, sob a égide da "liberdade de expressão", uma dada produção científico-biológica tem sido apropriada por discursos ultraconservadores, em grande parte de vertente fundamentalista religiosa, a fim de incitar moralmente o ódio e a violência contra as dissidências sexuais e de gênero. Para discutir este problema, partimos de teorizações dos Estudos de Gênero de vertente pós-estruturalista para investigar um conjunto de enunciados veiculados em perfis ultraconservadores e fundamentalistas religiosos ${ }^{3}$, com intuito de problematizar, justamente, os efeitos que tais enunciados provocam ao se apropriarem dessa produção científico-biológica sobre a homossexualidade e transexualidade. Esses efeitos aparecem, hoje, na reafirmação das terapias de reorientação sexual e em enunciados que operam como "proteção" à família nuclear, que alavancam a "Ideologia de Gênero", incidindo nas políticas públicas para a diversidade sexual e de gênero e, de modo especial, nas políticas do campo da educação.

\section{ULTRACONSERVADORISMO, FUNDAMENTALISMO RELIGIOSO E SEUS REFLEXOS NO CONTEXTO POLÍTICO ATUAL}

O fundamentalismo religioso, que é hoje, arriscamos dizer, aquilo que alicerça o ultraconservadorismo político brasileiro, tem sua origem no cristianismo, no ocidente e no protestantismo (ROCHA, 2009). Além disso, ele não é homogêneo e opera de modos distintos no mundo, sendo que o fenômeno vivenciado no Brasil está relacionado diretamente à emergência do fundamentalismo protestante nos

\footnotetext{
${ }^{3}$ Não se trata de personificar a complexidade da questão nesses perfis, nem "demonizá-los" como os únicos responsáveis pela disseminação de discurso de ódio no Brasil. Por isso, inclusive, é que não trazemos, aqui, os nomes dos donos desses perfis, já que não nos interessa, para a análise, quem é o sujeito empírico em questão. Queremos afastar a ideia de que esses perfis sejam as fontes originárias de produção desses discursos para posicioná-las como parte de uma rede discursiva - um fluxo, um feixe discursivo - da qual emerge o fenômeno fundamentalista religioso no Brasil atual, e cujos perfis mais atuantes nas mídias sociais são apenas uma das engrenagens.
} 
Estados Unidos de início do século XX, que preconiza a interpretação literal dos escritos da Bíblia como fundamental à vida e à doutrina (GALLO, 2009). Independentemente da vertente, é possivel dizer que os fundamentalismos religiosos "nasceram como perspectivas redentoras, como discursos salvadores em meio a uma condição de profunda insegurança e instabilidade" frente à modernidade (VILAS BÔAS, 2016, p.220). Consonantemente, Gallo (2009) aponta que a emergência do fundamentalismo reside em um niilismo realizado, já que a crise de fundamentos provocada pela modernidade, instigada pela cisão entre Ciência e pertencimentos religiosos, deixou desamparada uma multidão que já não podia encontrar um fundamento para viver e que, frente a inseguranças, agarrou-se a qualquer certeza provisória, mesmo que frágil.

Em sua concepção tradicional, o fundamentalismo religioso rejeita o tempo presente a partir da mobilização das camadas tradicionais da sociedadee de seus sistemas de valores aos sistemas tradicionais. Presentifica-se a noção de regresso aos fundamentos e a rejeição daquilo que não é considerado normal ou natural (LÉON, 2017), o que justifica a tese de que a emergência do fundamentalismo religioso contemporâneo no contexto brasileiro e o retorno de suas diferentes vertentes como forças imprevisíveis e de grande influência pode estar condicionada a um período marcado pelas lutas em torno da liberação sexual, dos direitos das mulheres e da diversidade sexual (VILAS BÔAS, 2016).

Por meio do emprego eficiente dos meios de comunicação, o fundamentalismo religioso, que hoje sustenta boa parte da argumentação política ultraconservadora brasileira, alçou posições de destaque não só na mídia, mas também no Congresso, fazendo com que seus discursos se tornassem influentes (VILAS BÔAS, 2016). Prova disso é o número de estações de rádio e canais de TV que pertencem a diferentes vertentes fundamentalistas religiosas, além do número exorbitante de deputados que compõem a Frente Parlamentar Evangélica, o que indica um grande apelo social pelas pautas de violência que ela representa, e demonstra o desejo e sua aceitabilidade no Brasil. Diferentemente do fundamentalismo religioso praticado em algumas localidades do oriente ${ }^{4}$, por exemplo, o fundamentalismo ocidental tem atuado nas políticas de saúde e, sobretudo, nas políticas voltadas à educação. Dentre essas iniciativas, condenam-se as pautas em prol do feminismo, do aborto, e das reivindicações para uma educação que abarque a diversidade sexual e de gênero, o que pode ser considerado unânime se levarmos em consideração o caráter deste movimento nos Estados Unidos, por exemplo (VILAS BÔAS, 2016).

Deste modo, a ênfase do fundamentalismo religioso ocidental recai sobre o controle da conduta sexual e de gênero. Este controle é explícito no contraponto necessário do culto à mulher casta e

\footnotetext{
${ }^{4}$ Para uma leitura e genealogia sobre os diferentes fundamentalismos religiosos, ver Vilas Bôas (2016).
} 
submissa, ao mesmo tempo em que há o rechaço aos gays afeminados, às pessoas trans e às mulheres ditas masculinizadas em relação à idealização do homem viril, autoritário e destemido, seja na forma da autoridade paterna, seja na bravura dos soldados da fé, como no caso dos ataques violentos aos terreiros de Candomblé e Umbanda no Brasil (VILAS BÔAS, 2016)5

A obsessão em torno das sexualidades e gêneros dissidentes bem pode ser entendida como o medo da destruição das relações engessadas entre os gêneros. 0 ideal de masculinidade é baseado na dominação sexual das mulheres e na discriminação da feminilidade, o que justifica porque gays afeminados são tão repudiados. Acredita-se que eles sejam uma paródia insuportável da feminilidade, que desafia a feminilidade servil e doméstica desejada, ao mesmo tempo em que essa feminilidade fere a masculinidade hegemônica. Nessa perspectiva, mulheres masculinizadas, homens afeminados e pessoas trans têm seus corpos e modos de viver deslegitimados porque não seriam "homens". 0 ódio contra as sexualidades e gêneros dissidentes não parte somente do ódio contra as práticas afetivas e/ ou sexuais entre gêneros semelhantes, mas também da misoginia e do sexismo. Paradoxalmente, essas formas de violência também guardam outra semelhança: elas causam e toleram a violência dirigida aos corpos, aos gêneros e às sexualidades que abominam (FONE, 2000).

No que concerne a essas experiências dissidentes, as consequências desse ultraconservadorismo e do fundamentalismo religioso variam desde a estigmatização, o desprezo, a rejeição familiar, a aplicação de penas legais em alguns países - como multa, flagelação, prisão, inclusive com trabalhos forçados, e até a morte (VILAS BÔAS, 2016). No Brasil, arriscamos dizer que o número crescente e assustador de assassinatos de gays, lésbicas, bissexuais, travestis e pessoas trans é uma condição que também reflete esse fanatismo, já que o fundamentalismo pode ser considerado como um outro lado do fascismo (GALLO, 2009). Foram 445 mortes LGBT em 2017 (GGB, 2017), um recorde vergonhoso não somente

\footnotetext{
${ }^{5}$ No que concerne às relações entre feminismo, liberdade política e fundamentalismo religioso, algumas produções oferecem previsões de um futuro sombrio oriundo dos fundamentalismos que vivenciamos na atualidade. A série The Handmaid's Tale, produzida pela plataforma Hulu, apresenta uma sociedade distópica ultraconservadora em que um grupo fundamentalista cristão toma o poder político nos Estados Unidos e estabelece um regime totalitário, hierárquico e fanático. No universo da série, devido à poluição ambiental e às infecções sexualmente transmissíveis, as taxas de fertilidade caíram drasticamente e poucas mulheres podem engravidar. Essas mulheres são transformadas em Handmaids de acordo com interpretações extremistas de contos bíblicos, e são designadas para famílias de elite, cujos "chefes de família" as estupram em ordem de gerar descendentes. De modo geral, todas as mulheres (sendo Handmaids ou não) são extremamente subjugadas - elas não podem trabalhar, possuir bens, e até mesmo ler. Interessantemente, há um paralelo assustador com o entendimento que o fundamentalismo religioso (não somente o cristão) da atualidade possui sobre as dissidências sexuais e de gênero. Ao decorrer dos episódios, executam-se pessoas dissidentes de sexo e gênero, consideradas "traidoras de gênero".
} 
brasileiro, mas mundial. Ou, de acordo com o fundamentalismo religioso, poderia se pensar que uma vez que as dissidências sexuais e de gênero "sempre" foram objeto de condenação religiosa (ao menos do catolicismo e do protestantismo), de repressão e criminalização por parte do Estado e de aversão social, a violência dirigida a essas dissidências, antes de ser "uma forma de fanatismo ou intolerância, ratifica os valores da sociedade e das instituições que a constituem e regem" (FONE, 2000, p. 573-574). Temse aí a reinterpretação de uma história de perseguição enquanto uma história de aplicação apropriada e "sensata" de justiça (seja ela qual for) e da manutenção da moralidade, da virtude e da ordem contra uma forma subversiva, antinatural e perigosa da conduta sexual (FONE, 2000).

\section{A PRODUÇÃO CIENTÍFICO-BIOLÓGICA SOBRE A HOMOSSEXUALIDADE COMO JUSTIFICATIVA PARA OS DISCURSOS ULTRACONSERVADORES E FUNDAMENTALISTAS}

Pensar em uma produção científico-biológica sobre a homossexualidade e transexualidade, por exemplo, tem se mostrado extremamente complexo, tanto pelos embates científicos, quanto pelas disputas nas arenas social e política contemporâneas, no que se refere à igualdade política para as sexualidades e gêneros dissidentes. De um lado, o que foi e ainda é escrito sobre as bases biológicas desses corpos é controverso, mas parece estar sempre rondando o espectro determinista versus salvacionista. Há quem diga que essas experiências são uma fatalidade de ordem genética, fisiológica ou endocrinológica. Há quem diga, também, que são uma doença ou, ainda, desvios de comportamento. Do outro lado (e, talvez, o mais atualizado), há um certo consenso de que é praticamente impossivel estabelecer causas biológicas "seguras", uma vez que pesquisas mais atuais rodeiam o já desgastado argumento, um tanto clichê inclusive, que aposta na combinação entre genética e fatores ambientais que, trocando em miúdos, também não significa dizer muita coisa.

Já no âmbito das discussões de políticas públicas, sob a égide da "Ideologia de Gênero", setores ultraconservadores e de cunho religioso fundamentalista impõem que as discussões de gênero não devem estar presentes nas escolas porque "conduziriam a humanidade à mente polimorficamente sexuada que destruiria a família", colocando em risco a saúde mental das crianças que poderiam "se transformar em gays, lésbicas e, até mesmo, travestis". Para justificar seus privilégios, apropriam-se (quando convém) da

\footnotetext{
${ }^{6}$ Como uma distorção do que Shulamith Firestone chama de "sexualidade polimorficamente diversa" em A Dialética do Sexo, tais expressões figuram no documento Informação /2015 enviado ao Ministério da Educação cobrando posicionamento sobre a recorrência da palavra gênero nos documentos educacionais. O requerimento pode ser acessado em: <http://twixar.me/95r>. Acesso em: ago. 2017.
} 
Biologia e de outros saberes científicos para assegurar seu poder e verdade de dizer que essas pessoas são "um mal a ser curado". Afinal, se não há como provar cientificamente que homossexualidade e transexualidade são um "fato da natureza", investe-se, pois, no argumento de que devem ser "desvios comportamentais" e, como tal, as terapias de reorientação sexual devem permanecer como "um direito a quem deseja mudar". Neste caso, há certa confusão conceitual quando se coloca sob o mesmo guardachuva as performatividades de gênero, os desejos e as práticas afetivo e/ou sexuais.

Investigando artigos científicos da área de saúde e Biologia publicados entre 1935 e 2003, encontramos noções extremamente perigosas sobre a homossexualidade e transexualidade, ora entendidas e produzidas como doença, ora entendidas como desvios de comportamento ou um risco de vida. Nosso interesse nesses materiais advinha da suspeita de que essa produção científico-biológica de outrora, tem figurado, no agora, em enunciados ultraconservadores, como os da Igreja Católica e, mais fortemente, das igrejas de vertente pentecostal e neopentecostal?. Para levar a cabo essa suspeita, no contexto do trabalho de pesquisa maior de onde se origina esse artigo, o caminho metodológico foi o de, em um primeiro momento, usar determinadas palavras-chave, como "LGBT", "gay", "lésbica", "homossexualidade" e "homossexualismo" para filtrar as contas do Twitter de perfis ultraconservadores e fundamentalistas religiosos publicamente reconhecidos por seu posicionamento odioso contra as sexualidades e gêneros dissidentes. Num segundo momento, a partir dos filtros aplicados, selecionamos os enunciados que diziam respeito à relação entre homossexualidade e/ou transexualidade e ultraconservadorismo ou fundamentalismo religioso. Nesse momento é que observamos, nos enunciados que iam sendo obtidos, a presença de uma argumentação científico-biológica sobre essas experiências, o que nos indicava que, de alguma forma, o ultraconservadorismo e o fundamentalismo religioso se apropriaram de uma dada produção científica para justificar sua disseminação de ódio contra determinados grupos sociais. Diante disso, o passo seguinte foi aplicar novos filtros, como "natural", "natureza", "biologia", "homem e mulher", "ciência", dentre outros, como forma de obtermos enunciados ainda mais específicos sobre essa relação entre ciência e ultraconservadorismo/fundamentalismo religioso. O passo seguinte foi fazer uma busca de artigos científicos sobre a homossexualidade e/ou transexualidade. Para isso, usamos algumas palavraschave na ferramenta de buscas do Google, como "bases biológicas da homossexualidade", "biology of

\footnotetext{
${ }^{7}$ As igrejas pentecostais compreendem as organizações que tiveram início no reavivamento estadunidense no começo do século XX. As principais igrejas pentecostais do Brasil são: Assembleia de Deus; Congregação Cristã no Brasil; Igreja do Evangelho Quadrangular; O Brasil para Cristo; e Deus é amor. As igrejas de vertente neopentecostais surgiram depois do movimento pentecostal, como um desdobramento. As principais representantes no Brasil são: Igreja Universal do Reino de Deus; Igreja da Graça; Sara Nossa Terra; e Renascer em Cristo.
} 
homosexuality", "endocrinology of homosexuality", "gay gene", dentre outras. Os artigos científicos foram selecionados porque evidenciam a repetição de enunciados deterministas sobre essas experiências e, além disso, nos fornecem pistas para pensar em como algumas noções sobre elas foram historicamente tecidas.

Cabe dizer, nesse sentido, que nos documentos científicos que analisamos na pesquisa que originou este texto há, sem dúvida, uma voracidade sobre os homens que se relacionam afetiva e/ou sexualmente com outros homens. No entanto, não estamos convencidos de que quando os documentos científicosbiológicos usam o termo "homossexuais" estão, de fato, falando exclusivamente de experiências ditas homossexuais masculinas. Algumas experiências descritas nesses documentos parecem estar mais próximas de experiências trans. Além disso, alguns documentos falam sobre experiências lésbicas. Ao mesmo tempo, os perfis fundamentalistas religiosos, cujos enunciados tomamos como objeto de análise, usam as expressões "ditadura gay", "homossexualismo" e "homossexualidade" para falar sobre qualquer dissidência sexual e de gênero. Portanto, se o ataque fundamentalista religioso é dirigido às formas de viver e expressar os gêneros e as sexualidades consideradas "não naturais" e "anormais", não seria incorreto dizer se tratar da produção discursiva das "dissidências sexuais e de gênero" e não somente da homossexualidade.

Diante dos dados que produzimos, é que questionamos: o quê, ou que condições permitem pontos de continuidade edescontinuidade entre os discursos científicos-biológicos e os discursos ultraconservadores e fundamentalistas religiosos quando se posicionam sobre os gêneros e as sexualidades dissidentes na contemporaneidade? Comparando enunciados de artigos científicos (Quadro 1), publicados em 1944 e 1980, comalgumas manifestações publicadas via Twitter, em perfis ultraconservadores efundamentalistas religiosos ${ }^{8}$, podemos perceber considerações etiológicas acerca das experiências dissidentes de sexo e gênero pensadas segundo os mesmos determinismos evocados pela história social e política de uma crise científica e social - a bicategorização impossivel e contraditória dos sexos (DORLIN, 2009):

\footnotetext{
${ }^{8}$ Embora não tenhamos traçado uma temporalidade específica, os tweets selecionados foram publicados entre 2011-2016. É importante ressaltar que os enunciados aqui apresentados são parte de um conjunto empírico maior, composto por outros tweets, além de recortes de matérias vinculadas em sites de notícia.
} 
Quadro 1 - Comparativo entre excertos de artigos científicos e enunciados publicados em perfis ultraconservadores e fundamentalistas no Twitter

Excertos de artigos científicos publicados entre 1944 e 1980

Os homens homossexuais femininos diferem de outros homens [...] A evidência de que, em tais indivíduos, um fenômeno biológico não presente nas pessoas assimchamadas saudáveis será apresentada neste relatório [...] (WILLIAMS, 1944, p.65-70, tradução livre)

[...] o comportamento dos homens homossexuais [...] tem como causa essencial um cérebro feminino diferenciado. (MACCULLOCH, 1980, p. 137, tradução livre)

Os homens homossexuais podem ser considerados como homens mais ou menos feminizados ou como verdadeiros intermediários sexuais masculinos, que são geneticamente femininos mas perderam todas as características morfológicas do sexo, exceto a fórmula cromossômica. (LANG, 1940, p.55-56, tradução livre)

Embora provavelmente seja verdade que, dadas certas condições, qualquer homem possa participar de atividades homossexuais, há uma grande diferença entre o homem que a faz como uma substituição para atividades heterossexuais e o indivíduo que, apesar de ter o físico masculino, tem o temperamento sexual feminino [...] Uma forma de expressão desta feminilidade é a preferência por assumir o papel feminino na relação sexual homossexual; indivíduos que designamos como homens homossexuais femininos. (WILLIAMS, 1944, p.70, tradução livre)
Enunciados publicados em perfis ultraconservadores e fundamentalistas no Twitter

Só existem 2 sexos. Macho e fêmea. Homem e mulher. Quem não aceita essa Nomenclatura (sic) propõe criar outra raça (sic) outra espécie, um mutante! (Tweet 1, 2012)

Estou pensando seriamente em assumir uma postura. Penso em abolir a palavra homossexual do meu vocabulário! Existe homem e mulher e ponto! (Tweet 2, 2012)

Masculino e feminino possuem diferenças genéticas, biológicas, anatômicas. O resto é conversa fiada de libertinos q (sic) querem destruir a família. (Tweet 3, 2016)

\#Faustão mostrando a natureza animal, a conquista entre o MACHO e a FÊMEA (Sic) Todos deveriam ver a verdade manifesta na natureza animal. (Tweet 4, 2014)

\section{Fonte: Elaborado pelos autores}

Supondo, como diz um dos tweets acima, que o programa televisivo apresentado por Faustão fosse uma fonte científica confiável e que "todos deveriam ver a verdade manifesta na natureza animal", todo o esforço teórico e político de biólogas feministas como Anne Fausto-Sterling, Ilana Lowy e Londa Schiebinger, por exemplo, nos mostrariam que a determinação do sexo não é tão simples e tampouco dicotômica. Tarefa muito mais complexa seria entender porque a "homossexualidade" é excluída da "natureza do sexo" como supõem os perfis fundamentalistas religiosos. Talvez por isso a insistência em afirmar que "menina é $X X$, menino é $X Y$ " ou "menina já nasce menina e menino já nasce menino", porque confere estabilidade de identidade. 0 que esses discursos ultraconservadores e fundamentalistas parecem propor é a afirmação do "sexo biológico" como ponto inexorável da natureza, de modo que os gêneros e 
as sexualidades dissidentes não possam coexistir com a conformação cisgênero e heterossexual, porque desafiam as leis da natureza e, consequentemente, as leis divinas.

Aliados a esses pressupostos, esses discursos ultraconservadores e fundamentalistas operam outras estratégias: primeiro, exploram as falhas deterministas dos conteúdos científicos-biológicos que cercam as investigações genéticas em prol das terapias de "cura gay" e, posteriormente, reforçam a importância dessas terapias ao inflamar antigos e novos pânicos morais, como o dispositivo da aids. Tomemos, como forma de visibilizar esse argumento, algumas manifestações extraídas de perfis ultraconservadores e fundamentalistas no Twitter:

NÃO ADIANTA XINGAR, verdade absoluta (sic), não existe natureza homossexual, o homossexualismo é um vício contra a natureza. (Tweet 5, 2015)

[...] Estudo científico aponta que é impossivel determinar a homossexualidade através do DNA [...] (Tweet 6, 2014)

[...] desconstruiu o mito de $q$ (sic) gay nasce gay. A [...] atordoou a todos $c+($ sic) de 12 fotos de ex-gays e hj (sic) pais da (sic) família. (Tweet 7, 2012)

A história da AIDS começou sim com homossexuais, isto é fato e ninguém pode negar (sic) é história e ponto final. (Tweet 8, 2012)

Cerca de meio milhão de pessoas no Brasil tem AIDS (sic) segundo a matéria do G1 a maioria (sic) são de jovens homossexuais. (Tweet 9, 2012).

As manifestações acima não estão preocupadas em refutar qualquer coisa sobre os determinismos científicos-biológicos, portanto, o objetivo delas não é afirmar que a homossexualidade não é genética. A questão é que, por meio dessa negação, outros significados são forjados por elas: I) se as sexualidades e gêneros dissidentes não são um destino genético, seriam, portanto, antinaturais. As pessoas "nasceriam com um sexo biológico heterossexual" e depois "aprenderiam" a ser homossexuais por experiências negativas sempre arraigas na psicologia, como: abuso sexual na infância, relacionamento problemático com a família etc.; II) como desvios de comportamento, poderiam ser mudados porque, sobretudo, há uma natureza heterossexual - prova disso seria a existência de "ex-gays"; e III) para somar força a esses argumentos, também "inventam" as sexualidades e gêneros dissidentes como um risco de vida à heterossexuais e à família nuclear, pela incitação moral evocada pelo dispositivo da aids/hiv. Nesse sentido, nos parece bastante visível a necessidade de uma economia dos discursos de verdade sobre "o homossexual" (FOUCAULT, 1988) para que as estratégias discursivas ultraconservadoras e fundamentalistas funcionem. Bem por isso os argumentos são contrários a uma essencialização das sexualidades e gêneros dissidentes e se aproximam mais de uma abordagem "construtivista", digamos assim, que abre espaço para a possibilidade de gerenciamento dos corpos na produção de uma sexualidade adequada aos pressupostos doutrinários (NATIVIDADE, 2006). 
Ainda que por uma questão de espaço para a tessitura deste texto não possamos esmiuçar todos os conteúdos científicos-biológicos nos enunciados ultraconservadores e fundamentalistas, é importante dizer que esses enunciados são evocados a partir de uma rede histórica de saber e poder que tão bem fez funcionar o dispositivo da sexualidade. Se pudéssemos ser mais específicos, diríamos que as discussões sobre os estudos da determinação do sexo que, por extrapolação, atestam a determinação da identidade de gênero e abrem espaço para as terapias de reorientação sexual estão articuladas aos efeitos da divisão entre sexo e gênero, isto é, o problema epistemológico que o próprio sexo representa, bem como o princípio de inteligibilidade conferido pelo sexo ${ }^{9}$. É do imbricamento dessas narrativas que, historicamente, as dissidências sexuais e de gênero são pensadas ora como um destino genético, ora como uma doença, ora como um desvio comportamental.

Nãoédifícil perceber que tanto os discursos científicos-biológicosquanto os discursosfundamentalistas religiosos não estão concentrados somente em um conjunto de proposições com conteúdos fixos. Essas estratégias que atuam na produção de violência são diversas, "[...] modelam os discursos públicos e privados, saturam todo o campo da representação cultural e, como o poder na concepção de Foucault, estão em todas as partes" (HALPERIN, 2007, p.53). Se, como diz Halperin (2007), devemos combater uma estratégia com outra estratégia, é possível, então, que a questão seja mais sobre discutir os motivos pelos quais o fundamentalismo religioso tem buscado esses determinismos científicos-biológicos sobre a homossexualidade e transexualidade e o efeito deste movimento no campo social, e menos sobre a veracidade ou utilidade desses determinismos na atualidade. Isto porque um movimento de contra discurso que busque este tipo de estratégia possa não ser muito profícuo, ou surtir efeito significativo, já que os discursos de ódio e violência são intencionalmente e constantemente renovados. Em outras palavras: mudam-se os argumentos, mas não sua finalidade. Refutá-los pode ser interessante em alguns contextos mas, de modo geral, parece ser inútil (HALPERIN, 2007).

Afinal, o que quer o ultraconservadorismo, especialmente o de vertente fundamentalista religiosa, com os discursos científicos-biológicos? Sabendo que os apontamentos feitos neste artigo estão permanentemente abertos a outras significações, algumas ideias possiveis podem ser articuladas. A primeira é que os discursos científicos-biológicos constituem um campo discursivo privilegiado para a significação epistêmica do corpo, do gênero e da sexualidade. Alguns exemplos básicos podem ser pensados a partir de determinados artefatos culturais: a) os livros didáticos de Ciências e de Biologia

\footnotetext{
${ }^{9}$ Essas discussões detalhadas podem ser encontradas na pesquisa de mestrado que originou este texto, ver Pereira (2018).
} 
ou as enciclopédias de educação sexual, em que historicamente esses discursos estão alocados ${ }^{10}$; b) as campanhas de prevenção da aids/hiv; c) os discursos midiáticos que suscitam vozes de especialistas para tratar o que consideram ser transtornos; d) alguns discursos militantes que requerem discursos naturalizantes em suas lutas; e) ou mesmo nossas próprias palavras quando recorremos a eles para justificar nossas supostas certezas. Ainda que sob diferentes pedagogias normalizadoras, ou associada a outros meios de divulgação mais incisivos, como a mídia e as mídias sociais, esses saberes científicobiológicos ainda desempenham forte papel na regulação dos modos de viver os corpos e os prazeres. Arriscamos dizer, inclusive, que essa regulação age com mais voracidade sobre os corpos transgêneros e intersexo e sobre as sexualidades dissidentes da heteronormatividade. Deste modo, se aceitarmos que a produção dos discursos científicos-biológicos sobre os corpos pode significar parte do processo histórico responsável pela estigmatização das dissidências de gênero e sexuais como uma ameaça à ordem social, desconfiamos que o movimento de apropriação desses discursos por parte do ultraconservadorismo possa ser, em parte, assim justificado.

\section{ULTRACONSERVADORISMO E FUNDAMENTALISMO RELIGIOSO E SEUS EFEITOS NAS POLÍTICAS PÚBLICAS}

Conforme tentamos expor, o discurso ultraconservador e fundamentalista assimilou uma produção científico-biológica determinista a fim de legitimar o status de doença e desvio que conferem às sexualidades e gêneros dissidentes. Ao mesmo tempo, usou esses discursos para afastar a ideia de que essas sexualidades pudessem ser um destino genético em prol de pressupostos das terapias de reorientação sexual, ou "cura gay". Não à toa que os projetos de lei $(\mathrm{PL})$ que atentam contra a diversidade sexual e de gênero apresentam justificativas arraigadas nos discursos científico-biológicos e, por vezes, nos discursos psi. Como exemplo, podem ser citados o Estatuto da Família, que definiu como família a composição homem, mulher e prole e a tentativa de revogação da resolução 001/99 do Conselho Federal de Psicologia (CFP)"11, que explicitamente requer a legitimação da "cura gay". Isso sem falar de projetos de lei arquivados, como a Criminalização da "Heterofobia" e a proibição da adoção de crianças por casais compostos por pessoas de mesmo gênero.

\footnotetext{
10 Para uma discussão aprofundada sobre os saberes produzidos pelas enciclopédias de educação sexual, bem como as redes de saber e poder que possibilitaram a legitimidade desses discursos quanto ao sexo, ao gênero e o desejo, ver a dissertação de Mikos (2017).

${ }^{11} \mathrm{~A}$ liminar concedida à "revogação" da resolução do CFP pode ser acessada neste link: <https://goo.gl/PNNAiY>.
} 
Neste momento, é importante dizer que a ascensão da cruzada fundamentalista religiosa no Brasil nos últimos anos pode ser entendida como uma forte reação a um período histórico (2002-2015) de parceria entre Estado e movimentos sociais, dentre eles, os movimentos LGBT, em prol da elaboração de políticas públicas, o atendimento às demandas de direitos civis e jurídicos, o fortalecimento de políticas de saúde, bem como a discussão da composição dos currículos educacionais que tangenciam a noção de diversidade (SIERRA, 2013; DAL'IGNA; SIERRA, 2018). Uma genealogia da última década, considerando "as propostas para a elaboração de políticas públicas voltadas para a promoção da igualdade de gênero e o respeito à diversidade sexual", como propõem César e Duarte (2017, p.146), nos mostra a instauração de um pânico moral em torno das dissidências sexuais e de gênero, desempenhada por reações violentas do fundamentalismo religioso contra qualquer avanço nas pautas LGBT, além do cerceamento às escolas, à produção científica (principalmente as produções e grupos de pesquisa que seguem a vertente dos Estudos de Gênero), bem como aos movimentos sociais, e às ações artísticas e políticas no país nos últimos anos ${ }^{12}$.

A primeira reação do fundamentalismo religioso a tomar grande proporção nas mídias sociais ocorreu em 2011, com o ataque ao projeto "Escola sem Homofobia", alcunhado pejorativamente de "Kit gay", cujos objetivos englobavam uma série de materiais de apoio para a abordagem dos temas diversidade sexual e gênero nas escolas, no intuito de combater as violências contra as sexualidades e gêneros dissidentes (CÉSAR; DUARTE, 2017). Nessa esteira, é possivel dizer que o Estatuto da Família aprovado em 2015 foi uma espécie de resposta à decisão do Supremo Tribunal Federal de aprovar a união jurídica de casais de

\footnotetext{
${ }^{12}$ Neste contexto, destacam-se o episódio turbulento da exposição Queermuseu - cartografias da diferença na arte brasileira, que reunia cerca de 270 obras com o tema diversidade sexual e de gênero. A exposição esteve em cartaz em Porto Alegre em agosto e setembro de 2017, quando foi encerrada abruptamente em função de protestos à instituição responsável pela exposição, incluindo agressões físicas e ameaças contra a curadoria da exposição, além da mobilização virtual massiva fundamentalista religiosa e do MBL (Movimento Brasil Livre) que acusavam a exposição de apologia à pedofilia e à zoofilia, além da profanação de símbolos religiosos. Semelhantemente, a performance La Bête, de Wagner Schwartz, que incluía a manifestação do público - que podia tocar o corpo de Schwartz, ou mesmo modificar sua posição, foi alvo de ataques. A performance ocorreu em uma única exibição no mês de setembro de 2017, no Museu de Arte Moderna (MAM) em São Paulo, e também foi alvo de manifestações violentas nas mídias sociais, inclusive, com a invasão do museu. Sob a acusação de pedofilia, o MBL publicou em suas redes sociais que a performance era repugnante, inaceitável, e promovia a erotização infantil - quando um vídeo de uma criança tocando os pés de Schwartz viralizou no Facebook. Marco Feliciano chegou a dizer que "destruidores da família" estariam envolvidos com a performance. Somados a esses episódios, está a reação exacerbada às visitas de Judith Butler ao Brasil, situação em que um grupo de manifestantes chegou a queimar um simulacro de Butler, ao estilo "queimem a bruxa" em frente ao Sesc Pompéia em São Paulo. Butler chegou a ser agredida no aeroporto de Congonhas por algumas pessoas, conforme mostra um vídeo veiculado nas mídias sociais. Dentre elas, duas mulheres que aos gritos chamavam Butler e sua companheira, Wendy Brown, de "pedófilas", "assassinas de crianças", "medíocres"; entre outras coisas, pode-se ouvir também um homem enaltecendo a agressão, dizendo "não à ideologia de gênero". O vídeo em questão pode ser acessado neste link: <https://goo.gl/KEi6LT>.
} 
mesmo gênero em 2013. Em seguida, o pânico moral teria sido acirrado nos embates acerca da redação e aprovação do PNE e seus desdobramentos nos Planos Estaduais e Municipais de Educação, sob a égide da famigerada "Ideologia de Gênero"13, que

[...] visa desmerecer e criminalizar a produção acadêmica e dos movimentos sociais em torno das questões relativas à igualdade de gênero e do respeito à diversidade sexual [...] um claro repúdio à produção acadêmica e intelectual que critica as concepções do corpo e da sexualidade como lugares naturalizados e que recusa denominar como patológicas as experiências de gênero e sexuais não-heteronormativas. (CÉSAR; DUARTE, 2017, p. 148).

Para o fundamentalismo religioso, a "Ideologia de Gênero" seria responsável por incentivar a erotização de crianças e, consequentemente, a pedofilia. Ela também objetivaria "mudar" o "sexo biológico e natural" das crianças ao dizer que o sexo e o gênero não são dados fixos e imutáveis dado por uma natureza cisgênero e heterossexual e que tampouco seguem a "trindade" sexo-gênero-desejo e/ou prática sexual e/ou afetiva. Em argumentos fantasiosos mais elaborados, comunistas tentariam implantar sua ideologia através do "gênero" para destruir a família nuclear, entendida como o sustentáculo da sociedade. Em outras palavras, trata-se de uma estratégia para a reafirmação de um modelo heteronormativo, machista, misógino e violento que usa da "preservação e proteção" da criança e da família como argumentos para se manter (MOREIRA, 2016).

Se os pânicos morais podem ser considerados como "aqueles que emergem a partir do medo social com relação às mudanças, especialmente as percebidas como repentinas e, talvez por isso mesmo, ameaçadoras" (MISKOLCl, 2007, p. 103), não é difícil perceber porque todas as ações relacionadas ao combate da promoção de direitos e de igualdade política para a diversidade sexual e de gênero tomadas pelo fundamentalismo religioso na última década parecem estar norteadas pela defesa da família nuclear. São ações que além de estabelecerem um efeito de causa - já que as sexualidades e gêneros dissidentes são inventadas como sendo responsáveis pela destruição eminente da família, dizem respeito a uma concepção a-histórica e acrítica a respeito dessa instituição, uma vez que a configuração familiar considerada legítima tem sua hegemonia simbólica mas nunca foi a regra, estando mais próxima de uma ficção, ou de um ideal coletivo (MISKOLCI, 2007). É em nome da família burguesa, nuclear e excludente, e da moral e dos bons costumes que essas cruzadas religiosas e morais têm assolado qualquer perspectiva de mudança nas políticas públicas que permita a liberdade das experiências de gênero e sexuais não

\footnotetext{
${ }^{13}$ Para uma genealogia da "Ideologia de Gênero", ver o texto completo de César e Duarte (2017).
} 
heteronormativas no Brasil. Aliás, não faltam pessoas dispostas a lutar e promover essa cruzada moral contra a "Ideologia de Gênero", como aparecem nos enunciados que tomamos em nossas análises:

A LEl é clara, a família q tem direito na educação moral dos filhos, ñ (sic) a escola. FORA IDEOLOGIA DE GÊNERO q (sic) quer erotizar crianças. (Tweet 10, 2016)

Eu defendo a família tradicional como fator protetivo social [...] (Tweet 11, 2014)

Não vamos desistir de lutar por um país melhor, seguiremos em frente em defesa dos ideiais (sic) da família cristã. (Tweet 12, 2016).

Alinhado à defesa da família, o investimento nas propostas de "cura gay" pode ser tomado como o evento mais recente dentro dessa série de investidas que estão sendo discutidas. A ação popular que gerou a decisão em caráter liminar de uma nova interpretação da resolução 001/99 do CFP argumenta que a resolução - que estabelece normas para profissionais de Psicologia no que concerne à orientação sexual, ao se opor à participação de eventos e oferta de serviços que proponham tratamento e cura de sexualidades dissidentes, é um ato de censura que restringe a liberdade de pesquisa científica assegurada pelo art. $5^{\circ}$ da Constituição, uma vez que, em seu entendimento, a resolução proíbe que profissionais da Psicologia desenvolvam estudos, atendimentos ou investigações científicas acerca dos comportamentos não-heterossexuais. 0 juiz da $14^{a}$ Vara do Distrito Federal entendeu que a resolução 001/99 do CFP, se mal interpretada, fere a liberdade científica, por isso, a decisão acatada foi a de que o CFP não impeça que profissionais realizem pesquisas e ofereçam atendimento acerca da reorientação sexual a quem, voluntariamente, procure-a.

Ora, o que está bem assegurado a partir da liminar é o escrutínio das experiências sexuais e de gênero dissidentes exclusivamente, já que os corpos cisgêneros e as sexualidades heterossexuais não constituem problema algum à moral brasileira. A ação movida pela missionária em "defesa" do progresso científico não é diferente do que os perfis fundamentalistas defendem, como pode ser notado nesses tweets:

Só no Brasil é proibido o psicólogo ajudar a um gay que quer deixar de ser, a ciência a serviço do ativismo gay, cambada de medíocres, VERGONHA. (Tweet 13, 2015)

[...] Não há cura para gays porque não há doença homossexual. Mentir sem parar é crime! (Tweet 14, 2013).

Se, como tentamos mostrar, esses enunciados "demonizavam" as experiências sexuais e de gênero dissidentes, por que há mudança de retórica quando o assunto é a "cura gay"? Para entender de que modo a tentativa de invalidar a resolução 001/99 do CFP é parte de uma orquestração fundamentalista, 
é pertinente esmiuçar brevemente o PL4931/2016 ${ }^{14}$, que segue tramitando na Comissão de Seguridade Social e Família da Câmara:

Art. $1^{\circ}$ Fica facultado ao profissional de saúde mental, atender e aplicar terapias e tratamentos científicos ao paciente diagnosticado com os transtornos psicológicos da orientação sexual egodistônica, transtorno da maturação sexual, transtorno do relacionamento sexual e transtorno do desenvolvimento sexual, visando auxiliar a mudança da orientação sexual, deixando o paciente de ser homossexual para ser heterossexual, desde que corresponda ao seu desejo. Art. $2^{\circ} 0$ profissional que atuar em atenção ao artigo anterior, não poderá sofrer qualquer sanção pelos órgãos de classe. (BRASIL, 2016, p. 1, grifo nosso).

A saber, o uso do termo "orientação sexual egodistônica", como propõe o $\mathrm{PL}$, pode ser considerado um erro conceitual, uma vez que o termo diz respeito a não vivência plena da sexualidade que pode ser experienciada independentemente do desejo e da prática sexual e/ou afetiva. Se a não vivência plena da sexualidade pode estar mais relacionada às sexualidades não-heterossexuais, o problema reside na violência à qual os sujeitos que as experienciam estão submetidos, não no desejo e na prática sexual e/ ou afetiva. Nesse sentido, o PL é muito explícito ao equiparar a homossexualidade a um distúrbio da orientação sexual, usando proposições do décimo Código Internacional de Doenças (CID-10):

Penso que a homossexualidade causa diversos transtornos psicológicos. No entanto,
visando não entrar, apenas, no campo religioso e para manter o debate no aspecto
científico destaco que a CID-10 elenca os seguintes transtornos: F66.0 Transtorno da
maturação sexual [...] F66.1 Orientação sexual egodistônica [...] F66.2 Transtorno do
relacionamento sexual [...] F66.8 Outros transtornos do desenvolvimento psicossexual
[...] F66.9 Transtorno do desenvolvimento sexual, não especificado [...]. Na verdade, o
que persiste na sociedade brasileira é exatamente a ideia propagada ostensivamente
por meio do discurso meramente ideológico desses grupos de interesse que, de modo
impressionante, convenceu grande parte da população brasileira de que não se podem
tratar os transtornos relacionados à orientação sexual, exceto no sentido (obrigatório)
de se levarem os portadores desses transtornos a aceitarem (sem questionamentos)
uma orientação sexual da qual, na verdade, eles próprios querem se livrar (BRASIL,
2016, p.2-4, grifo nosso).

Considerando o que diz este excerto do PL4931/2016, é possível até mesmo traçar um paralelo com as propostas de terapias de cura de início do século XX, já que o que se quer extirpar são transtornos.

${ }^{14} \mathrm{O}$ projeto de lei pode ser acessado em: <https://goo.gl/dE9HGp>. Acesso em jan. 2018. 
As técnicas de "correção" científicas das experiências dissidentes de gênero e sexo variavam desde a castração aos transplantes testiculares em homens, passando da indução de convulsões provocadas por substâncias químicas, ao tratamento com o eletrochoque - isso para citar alguns exemplos. Segundo Green (2000), no Brasil, o confinamento era o principal método terapêutico indicado para o tratamento e cura das perversões sexuais, de modo que a internação dos sujeitos era feita pela associação da degeneração física com a degeneração moral que a homossexualidade representava, sendo a afeminação considerada um dos traços mais eminentes de anormalidade ${ }^{15}$. Um excerto de um artigo científico publicado em 1940 pode nos ajudar a entender a questão:

Caso I. Um homem branco de 19 foi preso e sentenciado à prisão por depravação moral (homossexualidade). Foi liberado para tratamento e seria absolvido se sua perversão fosse corrigida. [...] Maneirismos femininos eram evidentes. Metrazol foi administrado até que quinze choques foram produzidos. Todos os desejos homossexuais desapareceram após o nono choque, mas o tratamento continuou até que todos os maneirismos femininos fossem removidos.[...] Foi-lhe concedida a absolvição. (OWENSBY, 1940, p.65, grifo nosso, tradução livre).

Pelo excerto destacado, nota-se que não seria suficiente que os desejos homossexuais desaparecessem, era preciso que qualquer traço de degenerescência fosse normalizado. Neste caso, o traço mais eminente era a feminilidade. 0 investimento científico sobre esses sujeitos significa a existência de um regime mais severo pela preocupação de exercer sobre eles um controle direto, e também nos mostra o deslocamento de um direito de morte para o poder sobre a vida, em que o poder passou a investir sobre a vida, administrando-a e regulando-a (FOUCAULT, 2015). Nesse sentido, a "cura" não só serviria de permuta para a pena imposta pela justiça, mas era cada vez mais necessária para a readmissão desses sujeitos na sociedade de ordem normalizadora. A reabilitação prometida pelo artigo em questão era a reabilitação da própria norma.

Embora as técnicas científico-biológicas de "correção" da homossexualidade tenham entrado em desuso, elas abriram espaço para outros tipos de terapias agora relacionadas aos saberes $p s i$. É justamente nessa roupagem que as terapias de "cura gay" da atualidade ressurgem como uma possibilidade de retorno à norma, como nos mostra dois outros tweets de perfis fundamentalistas religiosos:

\footnotetext{
${ }^{15}$ Apesar de não ter uma instituição específica para o tratamento desses sujeitos, alguns hospitais e sanatórios brasileiros aplicariam diferentes teorias e métodos mais incisivos importados dos Estados Unidos e da Europa, incluindo as terapias convulsivas e eletrochoques. Neste contexto, destacam-se o Hospital Psiquiátrico do Juquery e o Sanatório Pinel, ambos localizados em São Paulo.
} 
O homossexualismo é comportamental. (Tweet 14, 2011)

O QUE ACABO DE INFORMAR É CIÊNCIA. Homo (sic) é um comportamento como tantos outros. Eles querem o mesmo nivel de uma raça, uma piada! (Tweet 15, 2014).

Questionamos se o problema da "cura gay" não poderia estar relacionado a necessidade de coerência do sistema sexo-gênero-desejo que atravessa as relações sociais, afinal, não por acaso os discursos de ódio e violência contra as experiências dissidentes de sexo e gênero operam atribuindo a elas um "gênero danificado", chamando homens gays de "afeminados" e as lésbicas de "masculinas", por exemplo. Cria-se um terror aos atos sexuais dissidentes, um terror de "perder" o gênero - "não é um homem de verdade ou não é uma mulher de verdade", que desempenha um papel fundamental dentro de um dispositivo teórico que explica como a sexualidade é regulada por meio do controle e da humilhação de gênero (BUTLER, 1993). O medo da "degeneração sexual" é, pois, o medo das transformações em instituições como a família, é o medo da ameaça à reprodução biológica e aos frágeis papéis de gênero legitimados socialmente (MISKOLCI, 2007).

Por fim, entendemos que a propagação de discursos de ódio foi parte significativa dos processos responsáveis pela sedimentação das pautas fundamentalistas no Congresso Nacional, afetando sobremaneira as políticas públicas nesse campo, já que por essa via parece ter se instaurado uma vigia epistemológica constante em torno de palavras como família, gênero e sexo. Esse tipo de discurso insulta, assedia e intimida em virtude de pertencimentos étnico-raciais e culturais, de nacionalidade, de religião, de idade, de expressão de gênero e de sexualidade, mas também pode ser caracterizado pela capacidade de incitar ou disseminar a violência, o ódio e a discriminação em outras esferas (SANTOS, 2012). Essa incitação à discriminação também atravessa a subjetivação de noções deturpadas de determinados grupos sociais, como a produção das sexualidades e gêneros dissidentes como desvios da natureza, como doença e risco à família nuclear, por exemplo. Também é comum que esse tipo de discurso esteja disfarçado em argumentos de proteção moral e social, conforme explicitado pela cruzada moral pela família e pela "proteção" das crianças. Além disso, os discursos de ódio são abrandados pela "liberdade de expressão", o que tem tornado possível que agressões - veladas ou não - contra as dissidências sexuais e de gênero possam ser ditas sem qualquer consequência a quem as profira, afinal, como tão bem entoado, o fundamentalismo religioso supõe estar "falando de Ciência".

Não é nosso intento adentrar em estratégias pedagogizantes de dizer e classificar o que pode e o que não pode ser considerado discurso de ódio, além do mais, parece óbvio que por se tratar de discursos científicos não está eliminada a possibilidade de tal qualificação. Por isso, ainda que não seja nosso intuito estabelecer, aqui, efeitos de causa e consequência, ou culpabilizar exclusivamente certos perfis 
fundamentalistas religiosos pela violência causada às sexualidades e gêneros dissidentes, entendemos que elas atuam aprofundando as desigualdades sociais e a precariedade (BUTLER, 2015) a qual esses corpos estão submetidos, ao inflamar e propagar pânicos morais, uma vez que se apropriam de discursos que além de serem legitimados e privilegiados socialmente, estão fora do alcance da lei, por assim dizer. Considerando as terapias de "cura gay", por exemplo, tanto no conteúdo das propostas do PL4931/2016, quanto na liminar concedida à "revogação" da resolução 001/99 do CFP, em que se afirmou veladamente que as perspectivas de "cura gay" têm valor científico, anulou-se, supostamente, qualquer caráter de violência. Os conteúdos, por apelarem à legitimidade científica, são liberados. O que seria passível de punição são seus possíveis efeitos, que de uma forma ou de outra, não podem ser provados judicialmente.

\section{CONSIDERAÇÕES FINAIS}

Tentamos compor argumentos de que uma certa "diversidade" é produzida pelos saberes científicosbiológicos e apropriada pelos discursos ultraconservadores e fundamentalistas religiosos, buscando, assim, elementos de captura dos gêneros e sexualidades dissidentes para pensar como esses mecanismos se constroem, modificam-se e se tornam desejáveis na atualidade. Conforme exposto, a partir de determinismos que, historicamente, relegaram a diferença ao âmbito da patologia, do desvio e da normalização, o ultraconservadorismo e o fundamentalismo têm justificado suas ações violentas contra qualquer perspectiva política de se constituir uma vida mais vivivel e dissidente em relação à heteronormatividade (SIERRA, 2013). Essas estratégias deflagram as condições pelas quais esse fundamentalismo opera para reafirmar a importância de um retorno aos valores tradicionais, considerados como os bons e legítimos valores e não abrem espaço para dúvida: tratam-se de violências que intentam a aniquilação daquilo que expõe a insustentável fragilidade com que a heteronormatividade se mantém.

É importante ressaltar que, embora tenhamos destacado alguns enunciados presentificados no Twitter de perfis fundamentalistas religiosos, entendemos que não são vozes destoantes, mas que se somam ao coro ultraconservador, machista, misógino, racista e LGBTfóbico que vivenciamos na atualidade. De fato, o cenário atual não permite grandes expectativas: pânicos morais têm sido suscitados, como o dispositivo da aids/hiv, a "Ideologia de Gênero", além da "cura gay", o que nos mostra que o que parecia, em uma ligeira impressão, ser questão de "má-fé" e oportunismo é, ao contrário, estratégia não somente de normalização da diferença, mas da disputa hegemônica do discurso e da produção de condições insuportáveis para a sobrevivência. Em outras palavras, temos hoje, na polêmica, a incitação/excitação moral de sua força, culminando em uma relação profundamente assimétrica na distribuição de direitos civis, de proteção do Estado e de exposição à violência. 


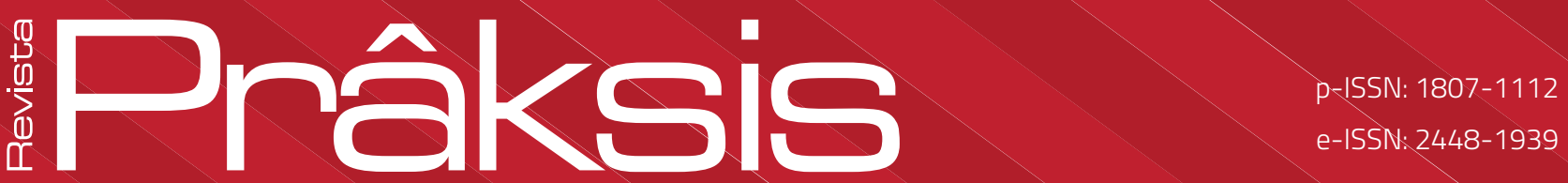

\section{REFERÊNCIAS}

BRASIL. Câmara dos Deputados. PROJETO DE LEI N 4931/2016 DE 2016. Disponível em:<https://goo. gl/9Pt8dq>. Acesso em jan. 2018.

BUTLER, Judith. Quadros de guerra. Quando a vida é passível de luto? Tradução de Sérgio Tadeu de Niemeyer Lamarão e Arnaldo Marques da Cunha; revisão de tradução de Marina Vargas; revisão técnica de Carla Rodrigues. $1^{\text {a }}$ ed. Rio de Janeiro: Civilização Brasileira, 2015.

. Critically queer. GLQ: a journal of lesbian \& gay studies. v. 1, p. 17-32, 1993. Disponível em:< https://goo.gl/gbvfgV> Acesso em jan. 2018.

CÉSAR, Maria Rita de Assis; DUARTE, André de Macedo. Governamento e pânico moral: corpo, gênero e diversidade sexual em tempos sombrios. Educar em Revista, Curitiba, v. 33, n. 66, p. 141-155, out./dez. 2017.

DAL'IGNA, Maria Cláudia; SIERRA, Jamil Cabral. Parceria e governamentalidade: ferramentas para problematizar as relações socioeducacionais contemporâneas. Educação Unisinos, v. 22, p. 332-340, 2018.

DORLIN, Elsa. Séxo, género y sexualidades. Introducción a la teoria feminista. Tradução de Victor Goldstein. Buenos Aires: Nueva Visión, 2009.

FONE, Byrne. Homofobia: Una historia. Tradução de Daniel Rey. México: Océano, 2000.

FOUCAULT, Michel. História da sexualidade I: A vontade de saber. Rio de Janeiro: Paz e Terra, 2015 Microfísica do poder. Rio de Janeiro: Graal, 1988.

GALLO, Silvio. A vila: microfacismos, fundamentalismo e educação. In: GALLO, Sílvio; VEIGA-NETO, Alfredo (Orgs.). Fundamentalismo e Educação. A vila. Belo Horizonte: Autêntica Editora, 2009, p. 17-35. GGB. Grupo Gay da Bahia. Assassinato de homossexuais (LGBT) no Brasil: relatório de 2017. Disponível em: <http://twixar.me/pfnK > Acesso em 10 mar. 2019.

GREEN, James. Além do carnaval. A homossexualidade masculina no Brasil do século XX. São Paulo: Editora Unesp, 2000.

HALPERIN, David. San Foucault. Para una hagiografia gay. Buenos Aires: El cuenco de Plata, 2007. 
LANG, Theo. Studies on the genetic determination of homosexuality. Journal of Nervous \& Mental Disease, v. 92, n.1, p.55-64, 1940.

LÉON, Adriano de. Fascismos em rede: uma mirada nos discursos de ódio pelas mãos de Foucault. In: SILVA, Francisco Vieira da; DOMINGOS, JJ; PEREIRA, Tânia Maria Augusto. (Orgs.). Foucault e Mídia. Entre pirotecnias e reflexões. Paraíba: Marca de Fantasia, 2017, p. 163-193.

MACCULLOCH, Malcolm. Biological aspects of homosexuality. Journal of Medical Ethics, v. 6, n. 3, p. 133-138, 1980. Disponivel em: <http://twixar.me/Psk>. Acesso em out. 2016.

MIKOS, Camila Macedo Ferreira. Produzir o sexo verdadeiro, regular o sexo educado: aproximações entre o cinema pornô e a educação sexual. 2017. 159 f. Dissertação (Mestrado em Educação)Universidade Federal do Paraná, Curitiba, Paraná, 2017.

MISKOLCl, Richard. Pânicos morais e controle social - reflexões sobre o casamento gay. Cadernos pagu, n. 28, p. 101-128, jan./jul.2007.

MOREIRA, Jasmine. Janelas Fechadas: o percurso da pauta LGBT no PNE 2014. 2016. 111 f. Dissertação (Mestrado em Educação) - Universidade Federal do Paraná, Curitiba, Paraná, 2016.

NATIVIDADE, Marcelo. Homossexualidade, gênero e cura em perspectivas pastorais evangélicas.

Revista Brasileira de Ciências Sociais, v. 21, n. 61, 2006.

OWENSBY, Newdigate M. Homosexuality and lesbianism treated with metrazol. Journal of Nervous \& Mental Disease, v. 92, n.1, p. 65-66, 1940.

PEREIRA, Tamires Tolomeotti. Ciência, Fundamentalismo religioso e Diversidade. A apropriação de discursos científicos-biológicos para a produção de ódio e violência contra as sexualidades e gêneros dissidentes nas mídias sociais. 2018. 143 f. Dissertação (Mestrado em Educação) - Universidade Federal do Paraná, Curitiba, Paraná, 2018.

ROCHA, Marisa Lopes da. Fundamentalismo e discussões contemporâneas acerca da crise da razão: implicações com as práticas educacionais. In: GALLO, Sílvio; VEIGA-NETO, Alfredo (Orgs.).

Fundamentalismo e Educação. A vila. Belo Horizonte: Autêntica Editora, 2009, p. 203-216. 
SANTOS, Karla Cristina. A problemática da constituição da ofensa no ato de insultar: a injúria como prática linguística discriminatória no Brasil. 2012. 136 f. Tese (Doutorado em Linguística) - Universidade Estadual de Campinas, Campinas, São Paulo, 2012.

SIERRA, Jamil Cabral. Marcos da vida viável, marcas da vida vivível: o governamento da diversidade sexual e o desafio de uma ética/estética pós-identitária para a teorização político- educacional LGBT. 2013. 231 f. Tese (Doutorado em Educação) - Universidade Federal do Paraná, Curitiba, Paraná, 2013. VILAS-BÔAS, João Paulo Simões. Niilismo, fanatismo e terror: uma leitura do fundamentalismo a partir de Friedrich Nietzsche. 2016. 270 f. Tese (Doutorado em Filosofia) - Universidade Estadual de Campinas, Campinas, São Paulo, 2016.

WILLIAMS, Edwin G. Homosexuality: a biological anomaly. Journal of Nervous \& Mental Disease, v. 99, n.1, p. 65, 1944. Disponível em:<https://goo.gl/29dAIN >. Acesso em: out. 2016. 